\title{
Distribution and population structure of the fish Cyphocharax gilbert (Characiformes: Curimatidae) in the Lower Paraíba do Sul River, Brazil
}

\author{
M.S. Menezes ${ }^{1} \&$ E.P. Caramaschi ${ }^{2}$ \\ 1 Depto. de Zoologia, SCB, UFPR, Caixa Postal 19020, CEP 81531-990, Curitiba, PR, Brasil; \\ marciamenezes@unicenp.br; \\ 2 Depto. de Ecologia, IB, UFRJ, Caixa Postal 68020, CEP 20941-970, Rio de Janeiro, RJ, Brasil; ericap@acd.ufrj.br
}

Received 25-V-2001. Corrected 11-IV-2007. Accepted 14-V-2007.

\begin{abstract}
The distribution and population structure of Cyphocharax gilbert in four areas of the lower Paraíba do Sul River and its major tributaries $\left(22^{\circ} \mathrm{S}, 43^{\circ} \mathrm{W}\right)$ were analyzed between March 1989 and February 1990. The species was common throughout the area, preferring major rivers with high turbidity and sand-mud substrates and range of length and size of specimens found varied depending on the particular characteristics of the site. A predominance of females was found in only area. Nevertheless, in all areas the bimonthly analysis showed preponderance of one of the sexes in periods before or after spawning. Males prevailed in shorter length classes and females in longer ones. There was a prevalence of young in one area that probably was used as a growth and feeding zone. Rev. Biol. Trop. 55 (3-4): 1015-1023. Epub 2007 December, 28.
\end{abstract}

Keywords: Curimatidae, distribution, population structure, sex ratio, Paraíba do Sul River, juveniles.

The Paraíba do Sul River is the largest fluvial drainage basin in Rio de Janeiro state and is the most important of the East basin (Menezes 1972) with distribution through the states of São Paulo, Rio de Janeiro and Minas Gerais in a total area of $57000 \mathrm{Km}^{2}\left(21^{\circ} 00^{\prime}\right.$ $\left.24^{\circ} 00^{\prime} \mathrm{S}, 46^{\circ} 00^{\prime}-41^{\circ} 20^{\prime} \mathrm{W}\right)$. The headwater of the Paraíba do Sul River is located at about an altitude of $1800 \mathrm{~m}$ in São Paulo state and flows into the Atlantic Ocean to the south from Rio de Janeiro state and has a length of approximately $1000 \mathrm{Km}$ (Baptista 1941).

A major project (ENGEVIX-FURNAS/ FUJB/UFRJ 1991) was carried out to complement environmental studies and it was an excellent opportunity to deepen our understanding of several local fish species.

The fishes were collected at different points along the lower area of the basin in Três Rios (RJ) (Fig. 1), an area characterized by a great diversity of habitats, with rapids, small waterfalls, lagoons, and marginal ponds.
The vegetation consisted mostly of herbaceous growth and small trees, as it was frequently

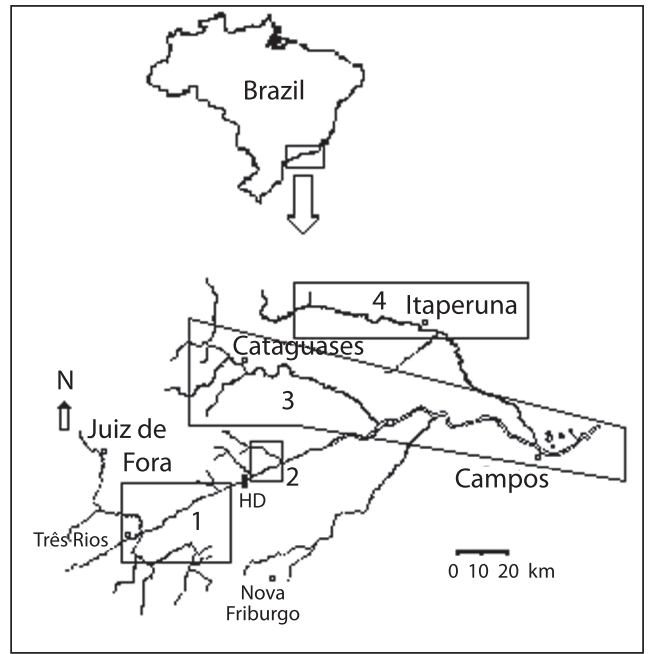

Fig. 1. Schematic map of the lower Paraíba do Sul River, indicating the four areas of occurrence of Cyphocharax gilbert and Ilha dos Pombos Hydroelectric Dam (HD). 
used for cattle grazing, and also had a few forest patches.

In area 1, there was prevalence of rapids with some marginal pools, dark water, great seasonal water level fluctuations and frequent sewage overflow along the area. Area 2, known as "the dead channel" of the Ilha dos Pombos Hydroeletric dam, had a great daily oscillation of water level due to the hydroeletric dam and contained a great amount of accumulated organic matter. In area 3, pools predominated (mainly ponds and channels), had dark water and small seasonal oscillation in the water level. In area 4, the water flowed at a moderate speed, was less turbid and had less accumulation of organic matter than in other areas.

The family Curimatidae is characterized by a complete absence of teeth in adults and by a thick gizzard-like stomach. They are filter feeders of the muddy riverbeds (e.g. Gneri and Angelescu 1951) consuming only the microscopic algae (Azevedo et al.1938). They constitute a major food source in the food web of the Paraíba do Sul River for other fishes, such as Hoplias malabaricus and Salminus maxillosus, as well as for other animales, such as birds and otters, as was commonly observed.

The presence of curimatids in lagoons and their shoaling habits were reported (Sazima and Caramaschi 1989) but there was no specific information on their distribution in habitats and possible differences in the population structure along the river. Parameters, such as length classes and sex ratio, are important tools to understand the population dynamics along a drainage basin.
The purpose of this paper is to analyze the distribution of Cyphocharax gilbert (Quoy and Gaimard 1824), its population structure dynamics, including variations in sex ratio, and to identify youth rearing areas.

\section{MATERIALS AND METHODS}

A total of 1129 specimens of Cyphocharax gilbert were collected in the basin of the Paraíba do Sul River in Três Rios (RJ). Some samples were deposited at the Ichthyological Collection in the "Museu Nacional do Rio de Janeiro" (samples 12845 to 12879). Samples were collected monthly from March 1989 to February 1990. A total of 132 sites were monitored using nets with meshes of varying sizes (15 to $70 \mathrm{~mm}$ ), manual drag nets (15 and $5 \mathrm{~mm}$ ), and seines.

Habitat characteristics were registered and categorized in Table 1 and in Figure 2 each frequency of occurrence is graphically depicted. Class and corresponding length intervales were obtained from Sturges' formulation (Silva and Souza 1987) and is listed in Table 2 and in Figure 3, the frequency of each size class of Cyphocharax gilbert is illustrated for each of the four areas studied. Figure 4 depicts for each area the frequency of occurrence by length class and by sex, verifying areas preferred by the young fish and those preferred by the adults.

The sample sites were grouped in four areas according to the geographic location: Area 1 (above the dam of the Ilha dos Pombos Hydroeletric), Area 2 (immediately under the dam of Ilha dos Pombos Hydroeletric), Area

TABLE 1

Features from the habitats in the "Paraiba do Sul" river

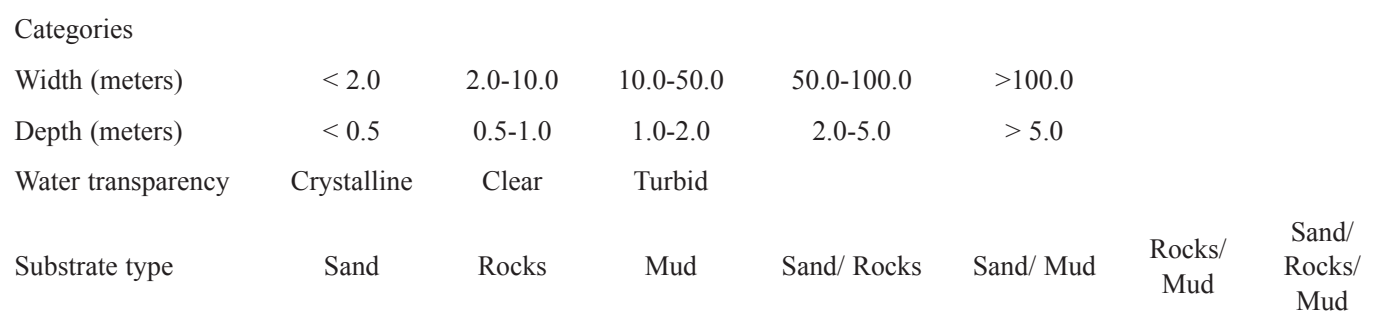


Width (meters)

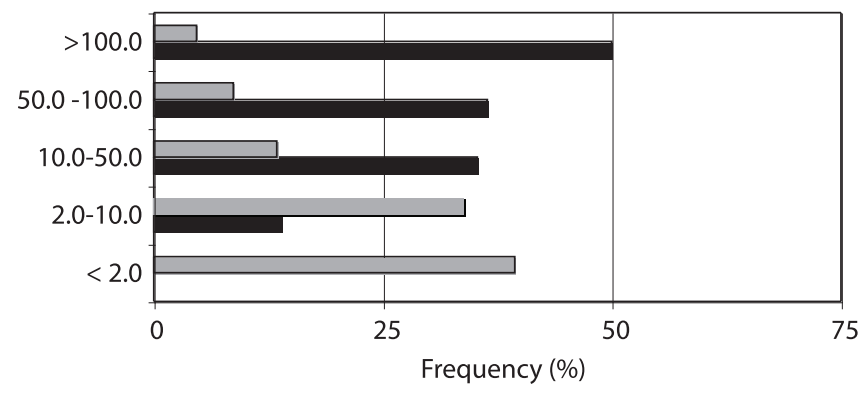

Depth (meters)
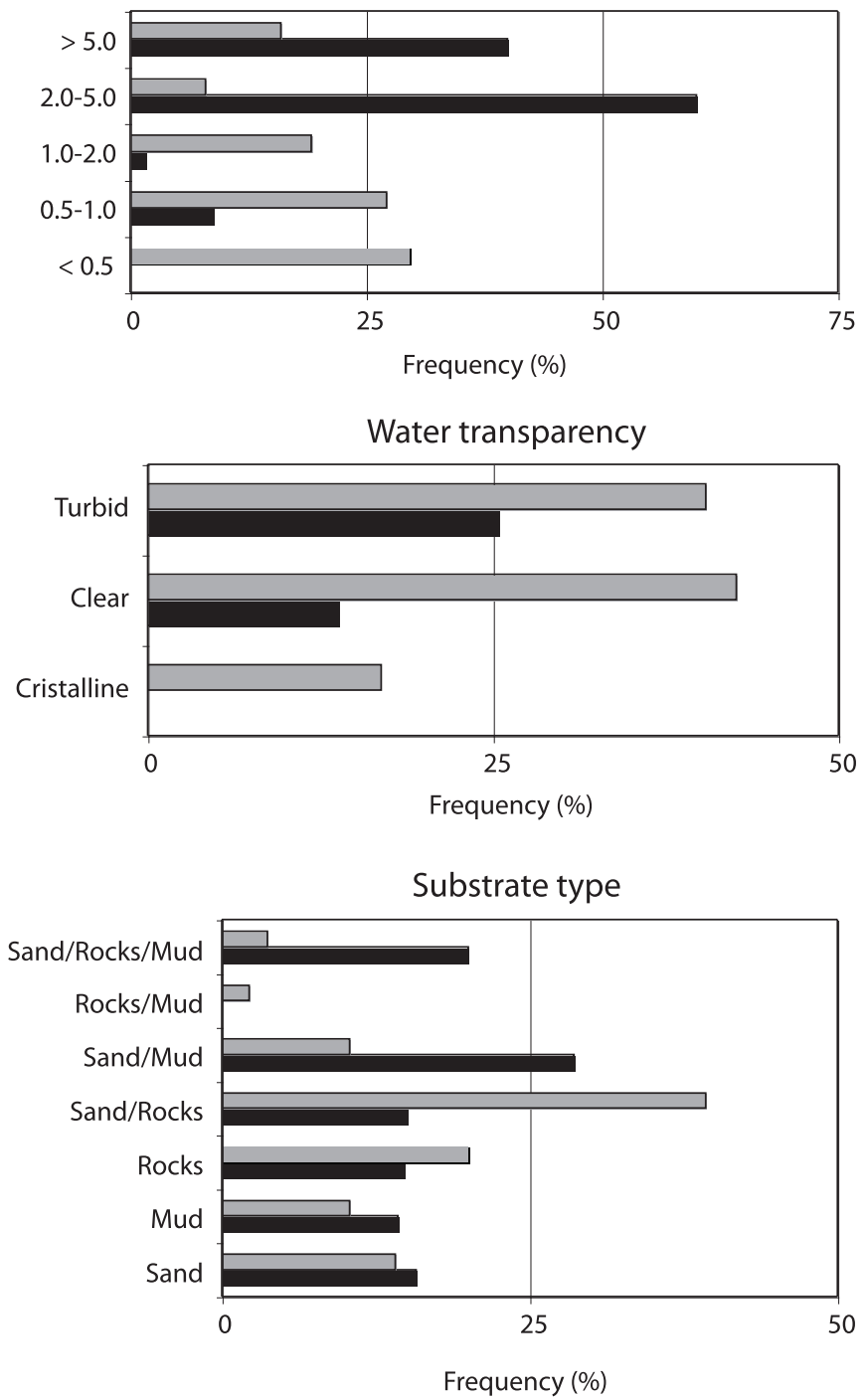

Fig. 2. Percent distribution of the habitat characteristics in the 136 sampled locations (gray bar) and the percentage of Cyphocharax gilbert found in each category (black bar). 
TABLE 2

Standard length classes of Cyphocharax gilbert

$\begin{array}{cc}\text { Classes } & \text { Intervals of size } \\ 1 & 2.0-3.7 \\ 2 & 3.7-5.4 \\ 3 & 5.4-7.1 \\ 4 & 7.1-8.8 \\ 5 & 8.8-10.5 \\ 6 & 10.5-12.2 \\ 7 & 12.2-13.9 \\ 8 & 13.9-15.6 \\ 9 & 15.6-17.3 \\ 10 & 17.3-19.0\end{array}$

3 (main channel of the Paraíba do Sul River, the Pomba River, the Dois Rios River, and the Cataia Lagoon), and Area 4 (the Muriaé River).

The individuals $(\mathrm{N}=890)$ were measured in centimeters and were dissected to identify their sex.The sex ratio of each length grouping and as a whole was calculated bimonthly and the statistical significance was corroborated by the $\chi^{2}$ test.

\section{RESULTS}

Cyphocharax gilbert was reported for 22 sites in a total of 136 sampled (Fig. 1). The species was preponderant in rivers at widths of greater than $100 \mathrm{~m}$ and at depths between 2 and $5 \mathrm{~m}$, and of the dark water and sand-muddy substrate type (Fig. 2).

Of the 1129 individuals collected, 343 $(30.4 \%)$ were collected in area 1, $133(11.8 \%)$ in area 2, $437(38.7 \%)$ in area 3, and 216 $(19.1 \%)$ in area 4. C. gilbert was reported in all four areas during the period studied, accounting for $100 \%$ of the specimen collected in area $1,91.7 \%$ in area $2,83.3 \%$ in area 3 and $91.7 \%$ in area 4.

C. gilbert presented standard-lengths varying between 2.06 and $20.5 \mathrm{~cm}$, which were categorized into 11 length classes increasing in increments of $1.7 \mathrm{~cm}$ (Table 2). In area 1, the fishes varied from class 2 to class 11 , and $67.0 \%$ of them belonged to classes 8 and 9 . In areas 2, 3 and 4, they varied from class 1 to 11 . In area $2,58.0 \%$ of fishes belonged to classes 8 and 9 . In area 3 , not one length class frequency reached $20.0 \%$; a total of $72.3 \%$ of the samples were distributed among classes 5 to 9 . In area 4, 51.3\% of fishes belonged to classes 5 and 6 (Fig. 3).

Males and females presented the same length classes in area 1 (class 4 to class 11), with $50.3 \%$ of males from class 8 , and $42.1 \%$ of females from class 9 (Fig. 4). In area 2, males presented length classes from 6 to 11 , with $67.5 \%$ belonging to classes 8 and 9 , while females varied from classes 4 to 11 , and $69.3 \%$ were in classes 8 and 9 (Fig. 4). In area 3 (Fig. 4), males varied from classes 3 to 10 , whereas females varied from classes 5 to 11 ; both sexes were predominant in classes 7,8 and $9(74.3 \%$ of males, and $63.4 \%$ of females). In area 4 (Fig. 4 ), males varied from class 4 to 10 , with $54.7 \%$ in classes 5 and 6 , whereas females representing classes 4 to 11, with classes 6 and 9 being most frequent $(23.1 \%$ and $27.7 \%$, respectively).

Taking into account the total number of individuals collected for the entire period studied, the sex ratio did not statistically deviate from 1:1; however, considering the sex ratio area by area, also for the entire period, differences were found only in area $2\left(\chi^{2}=12.9\right.$, $\mathrm{p}<0.05)$, evaluating the period as a whole. In area 1 , there was a higher percentage of males

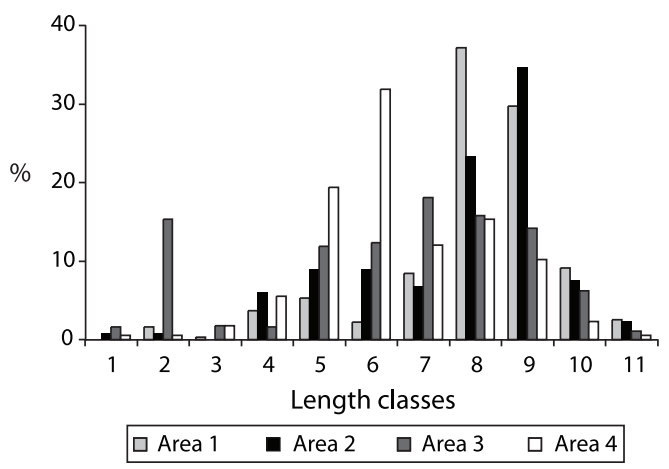

Fig. 3. Percent occurrence of standard length classes Cyphocharax gilbert in each sampled area. 
Area 1

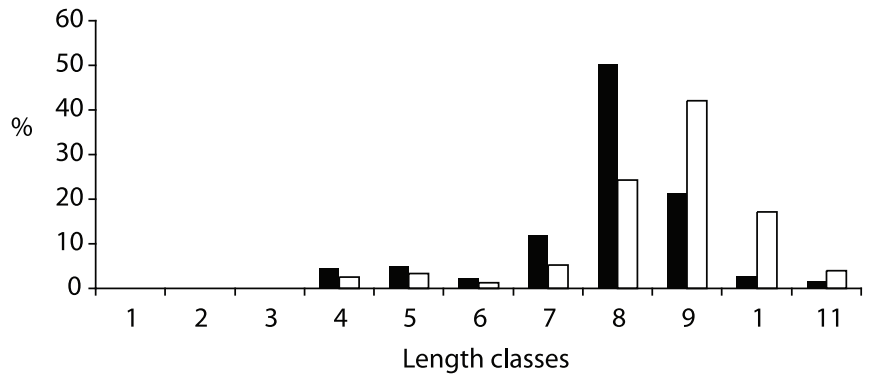

Area 2
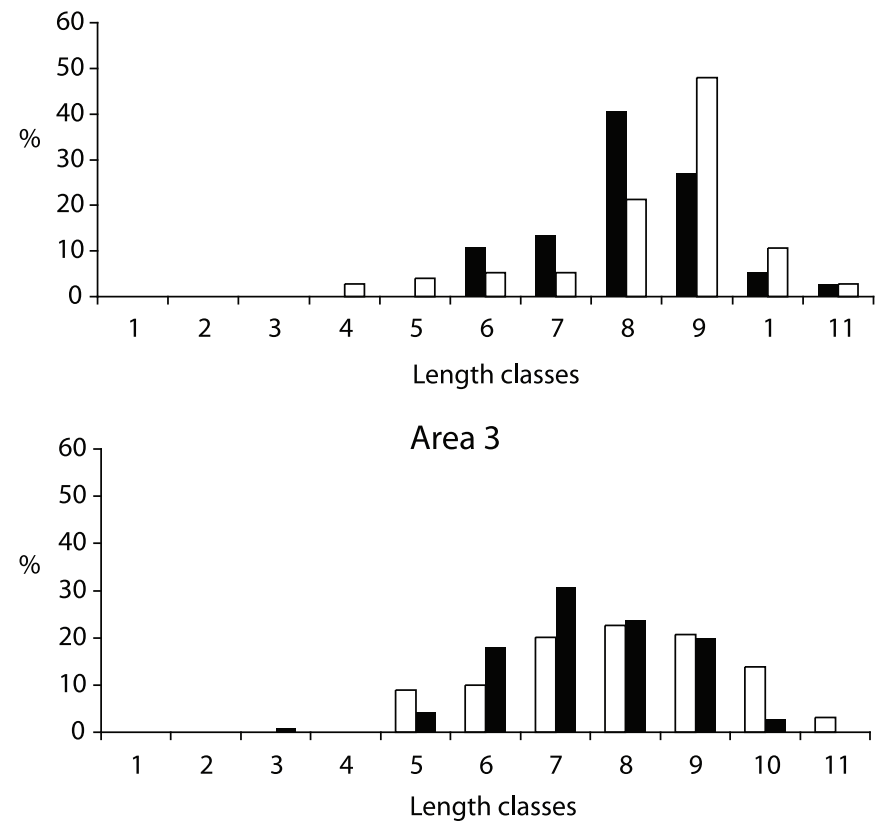

Area 4

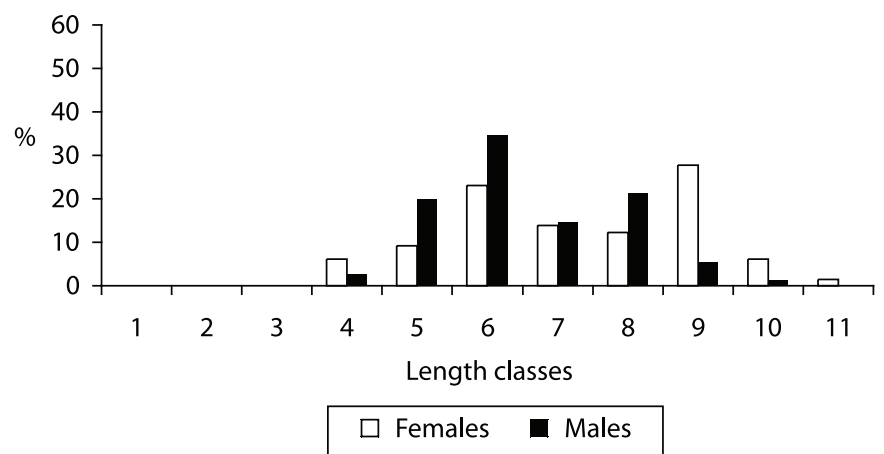

Fig. 4. Percent occurrence of standard length classes for each sex of Cyphocharax gilbert in all sampled areas. 
up to and including class 8 , with a statistical significance in classes $7 \quad\left(\chi^{2}=5.83, \mathrm{p}<0.05\right)$ and $8\left(\chi^{2}=19.59, \mathrm{p}<0.05\right)$. On the other hand, females were predominant in classes 9, 10 and 11, and it was statistically different in classes $9\left(\chi^{2}=6.63, \mathrm{p}<0.05\right)$ and $10\left(\chi^{2}=14.22\right.$, $\mathrm{p}<0.05)$. In area 2 , males prevailed in classes 6 and 7, even so the differences were not significant; females were predominant in classes 9 and 10 and significantly different in classes $9\left(\chi^{2}=14.69, \mathrm{p}<0.05\right)$ and $10\left(\chi^{2}=3.6, \mathrm{p}<0.05\right)$. In area 3, males prevailed in classes 6,7 and 8 , whereas females prevailed in classes 5 and 10 , with a significant difference in classes 5 $\left(\chi^{2}=11.64, \mathrm{p}<0.05\right)$ and $10\left(\chi^{2}=12.46, \mathrm{p}<0.05\right)$. In area 4 , only class 9 show a significant difference $\left(\chi^{2}=8.91, p<0.05\right)$, favoring females.

Analyzed by period (Fig. 5), males prevailed in July/August $\left(\chi^{2}=8.32, p<0.05\right)$ and in September/October $\left(\chi^{2}=5.26, \mathrm{p}<0.05\right)$ in area 1 . In area 2, September/October presented significant prevalence of females $\left(\chi^{2}=4.48, p<0.05\right)$. In areas 3 and 4 , January/February presented significant difference $\left(\chi^{2}=12.18\right.$ and $\chi^{2}=3.86$, $\mathrm{p}<0.05$ ), with a greater frequency of females.

\section{DISCUSSION}

Cyphocharax gilbert varied in percent occurrence in the sampled areas of the "Paraíba do Sul" River. The species was most frequent in area 3 , followed by area 1 , area 4 and, area 2. It is important to note that each of the areas possess its own unique set of characteristics.

The biggest captured fish was a female $(20.5 \mathrm{~cm})$ found in area 3 . It seems that this is a very close value to the maximum size reached by the species in this area at this time because in the past, nets with larger mesh sizes were efficient in the capture of the biggest species in the area.

In general, curimatid females reach greater lengths (e.g. Azevedo et al. 1938, Nomura and Taveira 1979, Nomura and Hayashi 1980, Taphorn and Lilyestro, 1983, Hartz and Barbieri 1994) and this was confirmed of the C. gilbert in the Paraíba do Sul River.
When considering the total number of individuals in all the sampled areas as a whole, the sex ratio of $C$. gilbert was not significantly different, but differences were found in area 2, which had a higher percentage of females than males. This can be explained by Nikolsky (1963), who reported that food availability was the main factor in determining sex. When there are limited food conditions, there is a prevalence of males in the population and, when food is plentiful, the population of females is greater. Our findings support this explanation: in area 2 , which is characterized by a great amount of organic matter, and thus, abundant food for the species, existed the conditions for a greater female population.

In addition to finding differences in the sex ratio in all areas studied along the "Paraíba do Sul" River, a further difference was found in the distribution of the size classes by the sex of the individual. There was a tendency to find more males of a smaller size and more females of a larger size. According to Santos (1982), females of greater lengths are part of a strategy of a species which spawns eggs without any parental care in order to face adverse conditions. Narahara et al. (1985) reported that there was a higher females mortality in the young phases but that females had greater longevity than males. We believe that the sexual dimorphism of C. gilbert of the Paraíba do Sul River is associated with the reproductive strategy of this species, which spawns many ova and does not exhibit any care to its offspring. This displacement exhibited between the sexes could explain the higher population of one of the sexes at certain times of the year and a higher population of the other at other times of the year. However, during times of high reproductive activity, the sex ratio is proportional. In fact, Krebs and Davis (1987) affirmed that it was quite common to find a large displacement of one of the sexes in birds and mammals.

Most studies on $C$. gilbert have analyzed population structure at just one site and not various; therefore, differences in sex ratio and size were not observed. However, Basile-Martins et al. (1986) verified that Pimelodus maculatus 
Area 1

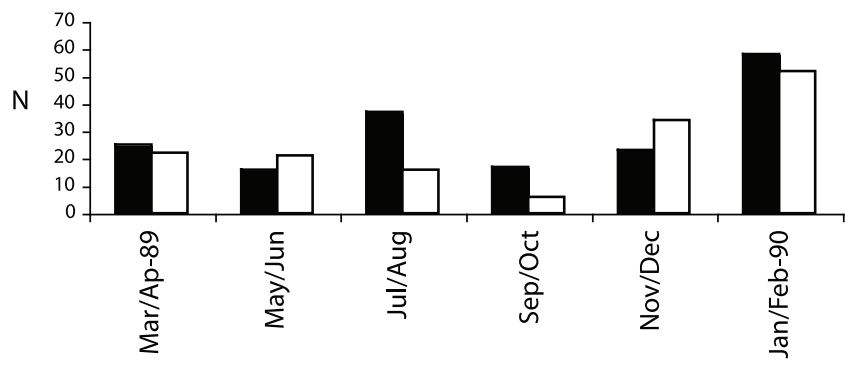

Area 2

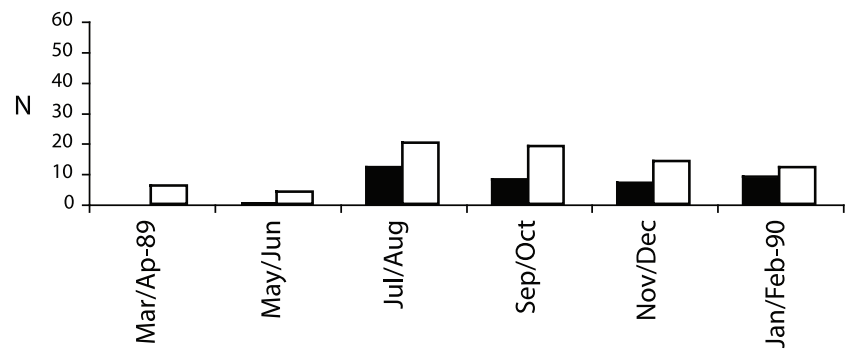

Area 3

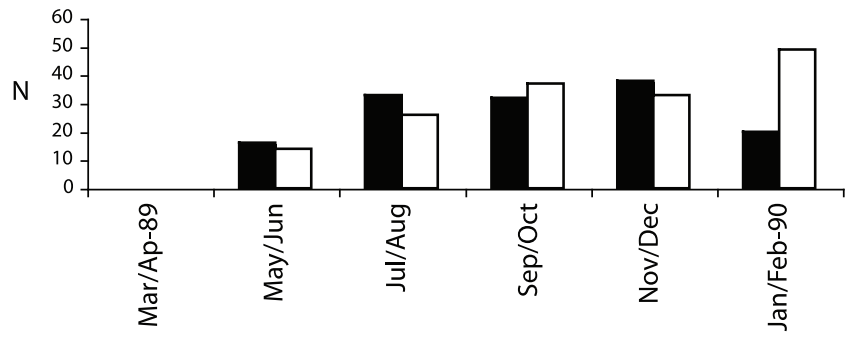

Area 4

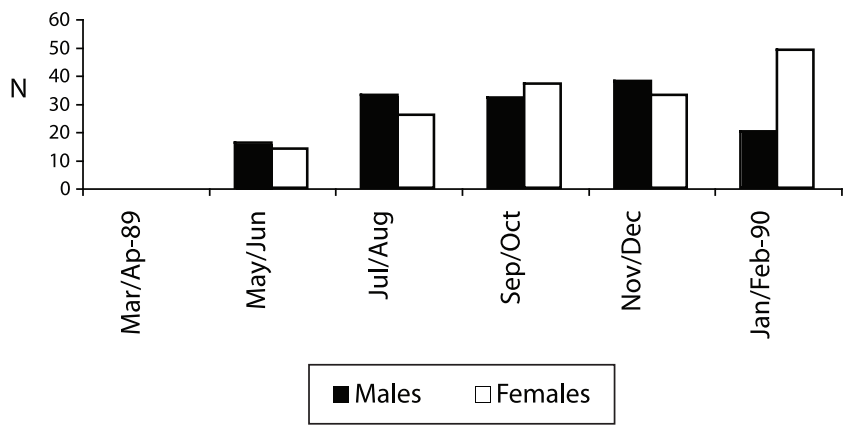

Fig. 5. Sex ratio of Cyphocharax gilbert during the sampled period in each area. 
exhibited differences in population structure in relation to sex ratio and behavior, as well as in size and age in different areas of the Jaguari and the Piracicaba Rivers (SP).

Different behaviors were observed in $C$. gilbert in different areas in relation to the population structure. In this study, despite the differences among the areas studied, we didn't consider them to constitute different populations. Although barriers existed isolating some of the areas, such as the Ilha dos Pombos Hydroeletric dam (between areas 1 and 2), and the distance which separates area 4 from the others, there existed the possibility, even if sporadic, of individuals from area 4 to arrive to the "Paraíba do Sul" River, and individuals from area 1 to enter area 2 (but not vice versa). However, considering that curimatids are fishes that live in shoals (Goulding 1980), it seems more parsimonious to suppose that shoals are used in displacements for feeding and reproductive aims. In that sense, the population structure of $C$. gilbert from the Paraíba do Sul River presented differences in the size structure in area 3 in relation to the others, mainly due to its high population of young, concentrated mostly in a marginal pond located in the lower most area of the whole extension studied. Considering that Menezes (1994) demonstrated that this was an area of reproductive intensity much lower than the others, we believe that this area is used for feeding, which is supported by the largest value of the condition factor registered by Menezes (op. cit.) in this area. We conclude, therefore, that Cyphocharax gilbert maintains a spatial continuity in extensive areas, which it uses for a different biological purposes, as seen in the areas studied of the Paraíba do Sul River.

\section{ACKNOWLEDGMENTS}

We are thankful to the team of icthyologists from the Laboratory of Vertebrates, Department of Ecology/UFRJ, for their assistance in field and laboratory work; to ENGEVIX-FURNAS/
FUJB/UFRJ for the financial support, and to $\mathrm{CNPq}$ for the scholarship given the first author.

\section{RESUMEN}

Se analizó aspectos de la distribución y estructura poblacional de Cyphocharax gilbert en cuatro diferentes áreas del cause bajo del Rio Paraíba do Sul y sus principales afluentes $\left(22^{\circ} \mathrm{S}, 43^{\circ} \mathrm{W}\right)$, entre marzo de 1989 y febrero de 1990. La especie fue común en toda su extención, ocupando preferentemente los ríos grandes con aguas turbias y substrato de arena-lodo. Los ámbitos de longitud y frecuencia de tamaños variaron con el lugar. Solo en una de las áreas hubo mayor proporción de hembras. Sin embargo, el análisis bimensual mostró una preponderancia de uno de los sexos en períodos antes y después del período reprodutivo en todas las áreas. Los machos prevalecen en los tamaños inferiores y las hembras en los superiores. Huvo una prevalencia de jóvenes en un área usada probablemente como una región para alimentación y crecimiento.

Palabras clave: Curimatidae, distribución, estructura de población, proporción de sexos, río "Paraíba do Sul", jóvenes.

\section{REFERENCES}

Azevedo, P. de, M.V. Dias \& B.B. Vieira. 1938. Biologia do saguiru. Mem. Inst. Oswaldo Cruz 33: 481559.

Baptista, C.D. 1941. Aspectos do vale do Paraíba e do seu regimento iniciado no governo Adhemar de Barros. Secretaria da Agricultura, Indústria e Comércio, Inst. Agronômico do estado de São Paulo em Campinas, Brazil.

Basile-Martins, M.A., H.M. Godinho, M.Y. Narahara, N. Fenerich-Verani \& M.N. Cipolli. 1986. Estrutura da população e distribuição espacial do mandi, Pimelodus maculatus Lacépède, 1803 (Osteichthyes, Pimelodidae), de trechos dos rios Jaguari e Piracicaba, São Paulo, Brasil. B. Inst. Pesca. 13: 399-410.

Engevix-Furnas/Fujb/Ufrj. 1991. Levantamento da ictiofauna do rio Paraíba do Sul e ciclo reprodutivo das principais espécies, no trecho compreendido entre Três Rios e Campos. Relatório final do Convênio ENGEVIX-FURNAS/FUJB/UFRJ, Rio de Janeiro. Vol. I- Levantamento e distribuição da ictiofauna.

Gneri, F.S. \& V. Angelescu. 1951. La nutrición de los peces iliofagos en relación con el metabolismo general del 
ambiente acuatico. Rev. Inst. Nac. C. Nat. anexo Mus. Arq. C. Nat. "B. Rivadavia", Ciencias Zool 2: 1-44.

Goulding, M. 1980. The fishes and the forest. Explorations in Amazonian natural history. University of California Press, Los Angeles, California, USA.

Hartz, S.M. \& G. Barbieri. 1994. Dinâmica da reprodução de Cyphocharax voga (Hensel, 1869) da lagoa Emboaba, RS, Brasil (Characiformes, Curimatidae). Rev. Brasil. Biol. 54: 459-468.

Krebs, J.R. \& N.B. Davies. 1987. An introduction to behavioural ecology. Blackwell Scientific, Oxford, England.

Menezes, M.S. 1994. Estrutura populacional e reprodução de Cyphocharax gilbert (Quoy \& Gaimard, 1824) (Osteichthyes, Curimatidae) no trecho inferior do rio Paraíba do Sul (RJ, MG) e principais afluentes. Dissertação de Mestrado. Universidade Federal do Paraná, Brasil

Menezes, N.A. 1972. Distribuição e origem da fauna de peixes de água doce das grandes bacias fluviais do Brasil. In-Poluição e Piscicultura, notas sobre poluição, ictiologia e piscicultura. Comissão interestadual da bacia do Paraná-Uruguai. São Paulo. Fac. Saúde Pública da USP e Inst. de Pesca da CPRN. pp. 73-78.

Narahara, M.Y., H.M. Godinho \& E. Romagosa. 1985. Estrutura da população de Rhamdia hilarii (Valenciennes, 1840) (Osteichthyes, Siluriformes, Pimelodidade). B. Inst. Pesca, 12(3): 123-137.
Nikolsky, G.V. 1963. The ecology of fishes. Academic, London.

Nomura, H. \& C. Hayashi. 1980. Caracteres merísticos e biologia do saguiru, Curimatus gilberti (Quoy \& Gaimard, 1824), do rio Morgado (Matao, São Paulo) (Osteichthyes, Curimatidae). Rev. Brasil. Biol. 40: 165176.

Nomura, H. \& A.C.D. Taveira. 1979. Biologia do saguiru, Curimata elegans Steindachner, 1874 do rio Mogi Guaçu, São Paulo (Osteichthyes, Curimatidae). Rev. Brasil. Biol. 39: 331339.

Santos, G.M. 1982. Caracterização, hábitos alimentares e reprodutivos de quatro espécies de "aracus" e considerações ecológicas sobre o grupo no lago JanauacáAM (Osteichthyes, Characoidei, Anostomidae). Acta Amazônica. 12: 713739.

Sazima, I. \& E.P. Caramaschi. 1989. Comportamento alimentar de duas espécies de Curimata sintópicas no Pantanal de Mato Grosso (Osteichthyes, Characiformes). Rev. Brasil. Biol. 49: 325333.

Silva, J.X. \& M.J.L. Souza. 1987. Análise ambiental. Universidade Federal do Rio de Janeiro, R. Janeiro, Brazil.

Taphorn, D.C. \& G.G. Lilyestrom. 1983. La relación pesolargo, fecundidad y dimorfismo sexual de Curimatus magdalenae (Pisces, Curimatidae) de la cuenca del lago Maracaibo, Venezuela. Mems. Soc. Cienc. Nat. la Salle, Caracas 43: 2937. 
